\%

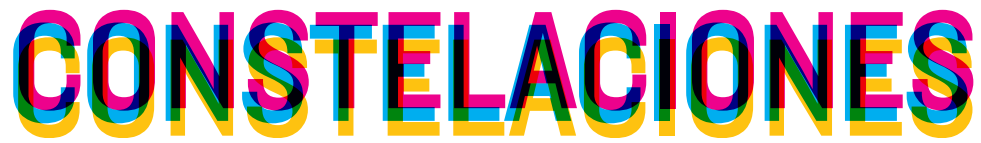

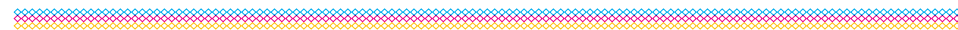


CONSTELACIONES n², mayo 2014

Revista de Arquitectura de la Universidad CEU San Pablo

Architecture Magazine of CEU San Pablo University

Periodicidad anual

Annual periodicity

COMITÉ DE REDACCIÓN EDITORIAL COMMITTEE

\section{Director Director}

Juan García Millán

Jefa de Redacción Editor in Chief

Covadonga Lorenzo Cueva

Secretario de Redacción Editorial Clerk

Rodrigo Núñez Carrasco

Maquetación y producción Design and production

María Fernández Hernández

Vocales Board Members

Fernando del Ama Gonzalo. Escuela Politécnica Superior, Universidad CEU San Pablo, Madrid

Pablo Campos Calvo-Sotelo. Escuela Politécnica Superior, Universidad CEU San Pablo, Madrid

Alfonso Díaz Segura Escuela Superior de Enseñanzas Técnicas, Universidad CEU Cardenal Herrera, Valencia

Mayka García Hípola. Escuela Politécnica Superior, Universidad CEU San Pablo, Madrid

Sonia Izquierdo Esteban. Escuela Politécnica Superior, Universidad CEU San Pablo, Madrid

Javier Sáenz Guerra. Escuela Politécnica Superior, Universidad CEU San Pablo, Madrid

\section{CONSEJO EDITORIAL EDITORIAL BOARD}

Beatriz Colomina. School of Architecture, Princeton University, New Jersey

Carmen Díez Medina. Escuela de Ingeniería y Arquitectura, Universidad de Zaragoza

María Antonia Frías Sargadoy. Escuela Técnica Superior de Arquitectura, Universidad de Navarra

Ángel González García. Facultad de Geografía e Historia, Universidad Complutense de Madrid

Juan Miguel Hernández Léon. Escuela Técnica Superior de Arquitectura, Universidad Politécnica de Madrid

Juan José Lahuerta Alsina. Escuela Técnica Superior de Arquitectura, Universidad Politécnica de Cataluña, Barcelona

Eduardo Leira Sánchez. Ex director del Plan General de Ordenación Urbana, Madrid

Joaquín Medina Wamburg. Facultad de Aquitectura Diseño y Urbanismo, Universidad de Buenos Aires

Zaida Muxí Martínez. Escuela Técnica Superior de Arquitectura, Universidad Politécnica de Cataluña, Barcelona

José Joaquín Parra Bañón. Escuela Técnica Superior de Arquitectura, Universidad de Sevilla

Víctor Pérez Escolano. Escuela Técnica Superior de Arquitectura, Universidad de Sevilla

Fernando Pérez Oyarzún. Escuela de Arquitectura y Diseño, Pontificia Universidad Católica, Santiago de Chile Judith Sheine. School of Architecture and Allied Arts, University of Oregon, Portland

Andrés Walliser Martínez. Global Design, New York University, Nueva York

\section{ISSN 2340-177X}

Depósito legal M-13872-2013

(c) de los textos, sus autores

(c) de las imágenes autorizadas

(c) Revista Constelaciones

๑) Escuela Politécnica Superior, Universidad CEU San Pablo

Universidad CEU San Pablo

Escuela Politécnica Superior

Urbanización Montepríncipe, $s / n$

Boadilla del Monte, 28668. Madrid (España)

constelaciones@eps.ceu.es

www.uspceu.es

Edición Edition

Fundación Universitaria San Pablo CEU

Madrid, España

Impresión Printing

VA Impresores

Impreso en España Printed in Spain

Distribución Distribution

CEU Ediciones

Los textos que componen Constelaciones se obtienen mediante convocatoria pública. Para que los trabajos recibidos entren en el proceso de selección de los artículos a publicar deben ser trabajos originales no publicados anteriormene, con una extensión recomendada de 3.000 palabras, título, resumen (un máximo de 150 palabras) y palabras clave (un mínimo de cuatro palabras), en español y en inglés. Tras haber cumplido estos requisitos (y los correspondientes incluidos en las normas editoriales de la revista, disponibles para consulta en formato digital desde el comienzo de la convocatoria), tiene lugar un proceso de revisión y evaluación de los artículos previa aceptación de los mismos para su publicación. Para acometer dicho proceso, y con el fin de asegurar la calidad de los contenidos, la Revista Constelaciones recurre a evaluadores externos a la institución editora y anónimos (cada artículo es evaluado por dos de ellos) encargados de someter a crítica los mismos. Todos los artículos de investigación publicados en esta revista han pasado por dicho proceso. La recepción de artículos se extendió hasta el 30 de Septiembre de 2013. Texts included in Constelaciones are obtained by public announcement. Only original papers that have not been previously published will be included in the process of selection of articles. They should not exceed 3.000 words and should include a title, an abstract (no more than 150 words) and keywords (a minimum of four words), in Spanish and English. After having fulfilled these requirements (and those included in magazine editorial standards, available for consultation from the beginning of the Call for Papers), occurs a process of review and evaluation of articles upon acceptance of them for publication. To undertake this process, and in order to ensure the quality of the contents, Constelaciones turns to external and anonymous evaluators to the institution (each article is evaluated by two of them) responsible for the critic. All the articles published in this journal have undergone this process. The deadline for reception was extended until September 30, 2013.

Todos los derechos reservados. Esta publicación no puede ser reproducida, ni en todo ni en parte, ni registrada, ni transmitida, ni almacenada en ningúna forma ni por ningún medio, sin la autorización previa y por escrito del equipo editorial. En este número se han utilizado algunas imágenes de las que no se ha podido identificar al propietario de los derechos. En estos casos hemos entendido que las imágenes son de libre uso. En caso de identificar alguna de estas imágenes como propia, por favor, póngase en contacto con la redacción de Constelaciones. Los criterios expuestos en los diversos artículos de la revista, son responsabilidad exclusiva de sus autores, y no reflejan necesariamente los que pueda tener el equipo editoral. El equipo editorial de la revista no se responsabiliza de devolver la información enviada a la redacción a no ser que se le solicite expresamente. All rights reserved. This publication cannot be reproduced, in whole or in part, nor registered, transmitted or stored in any form or by any means, without the written permission of the Editorial team, In this issue some images were used without knowing the owner of the rights. In these cases, we have understood that the images are free of use. In case you identify written permission of the Editorial team, In this issue some images were used without knowing the owner of the rights. In these cases, we have understood that the images are free of use. In case you identify
any of these images as your own, please, contact with the Editorial staff of Constelaciones. The opinions expressed in this issues's articles are entirely the responsibility of their authors and are not necessarily shared by the editors of this journal. The publisher don't take responsibility for returning submitted material which is not expressly requested. 


$$
11
$$




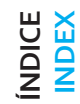

$\stackrel{n}{\sim}$

ร

5

$\curvearrowright$

๙ิ

$\stackrel{n}{=}$

$\bar{m}$
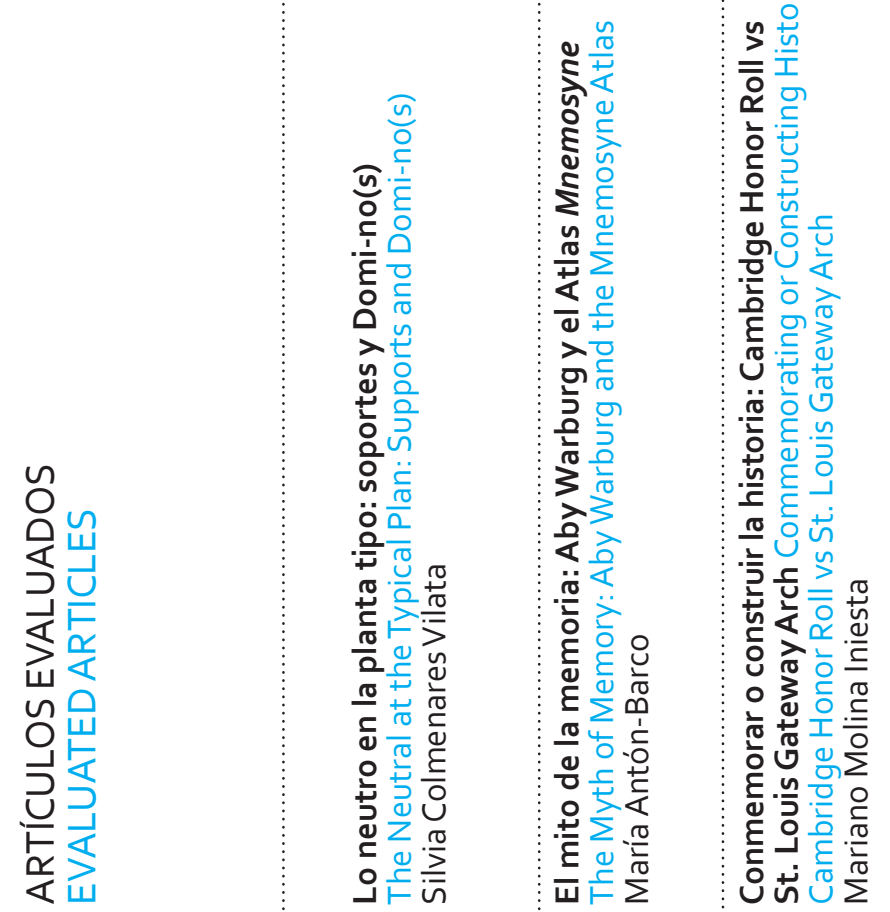

旁 을

‥

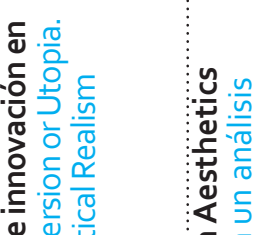

앙

胥苞

$\bar{\Psi}$

宛

일

능홍

区告

음 흠

응 흥

\%

든

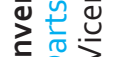

ข

음

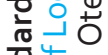

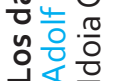

a व

은

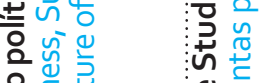

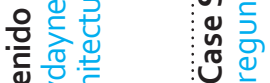

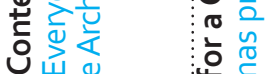

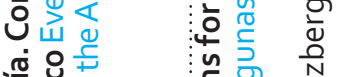

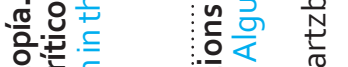

गे

गे० गे ये ज

:

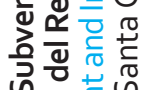

है

ज०

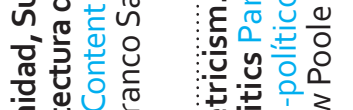

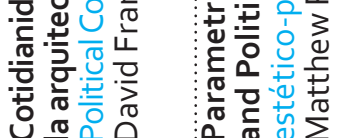

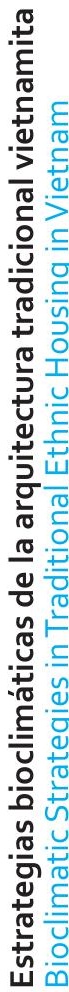

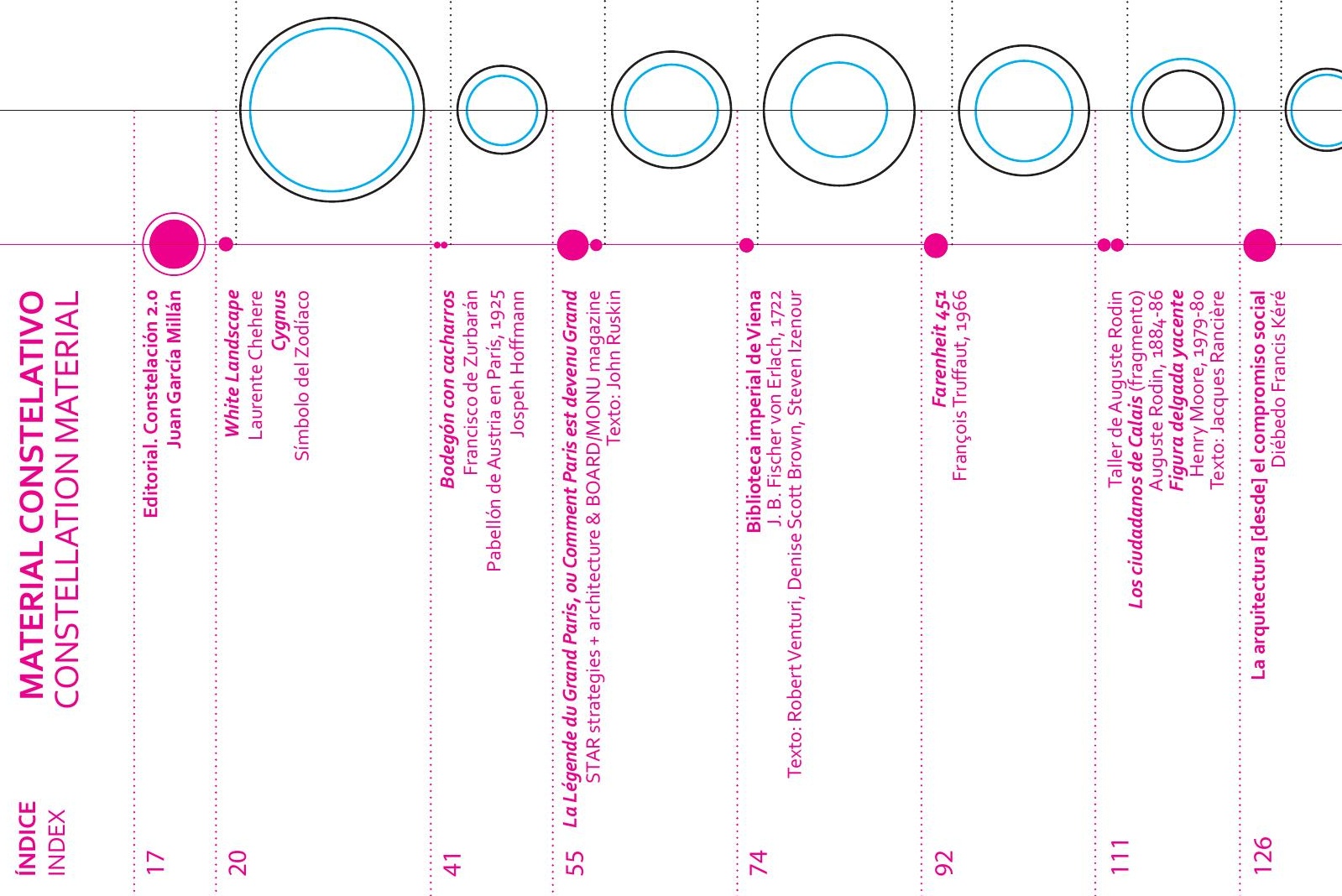

苍

० 


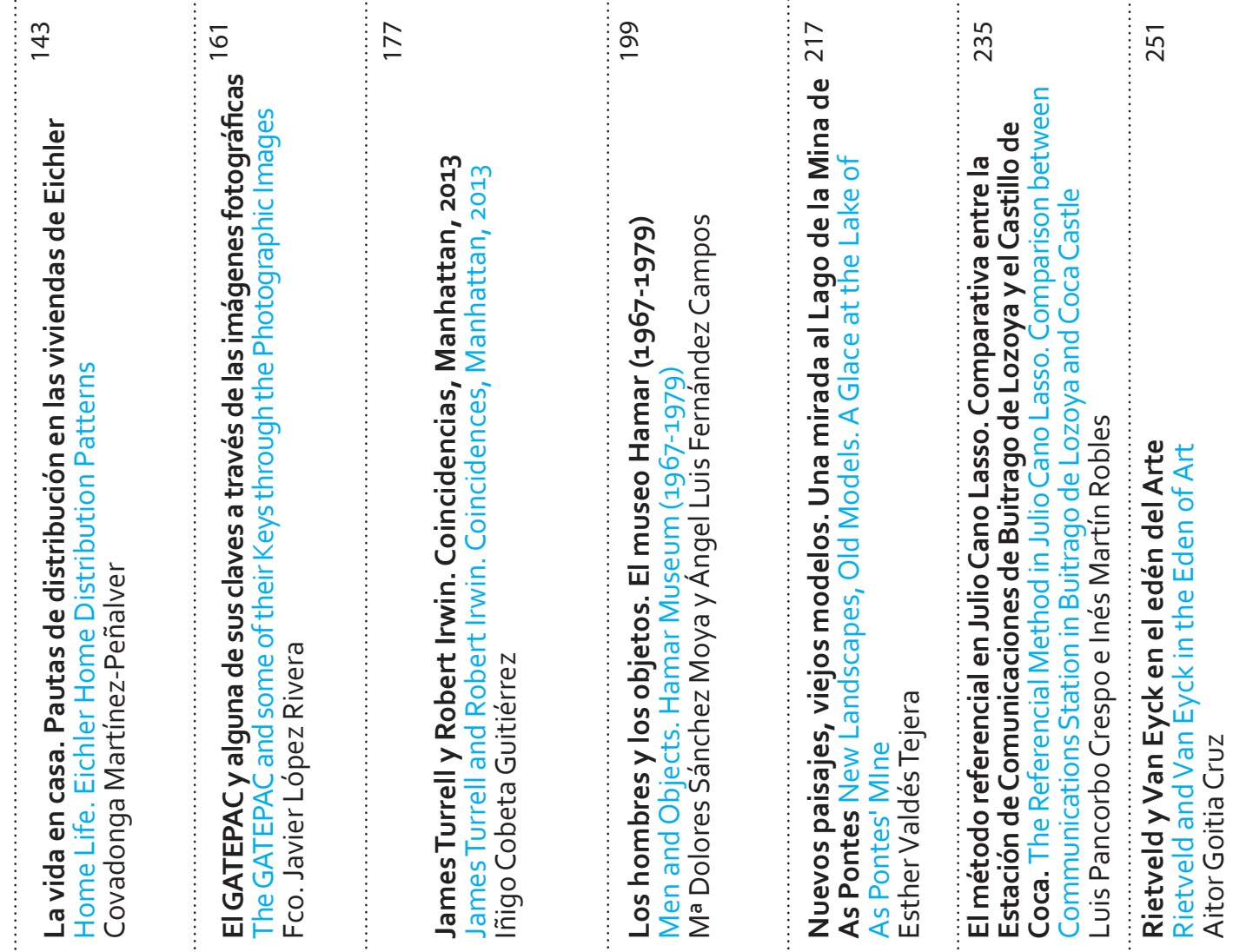
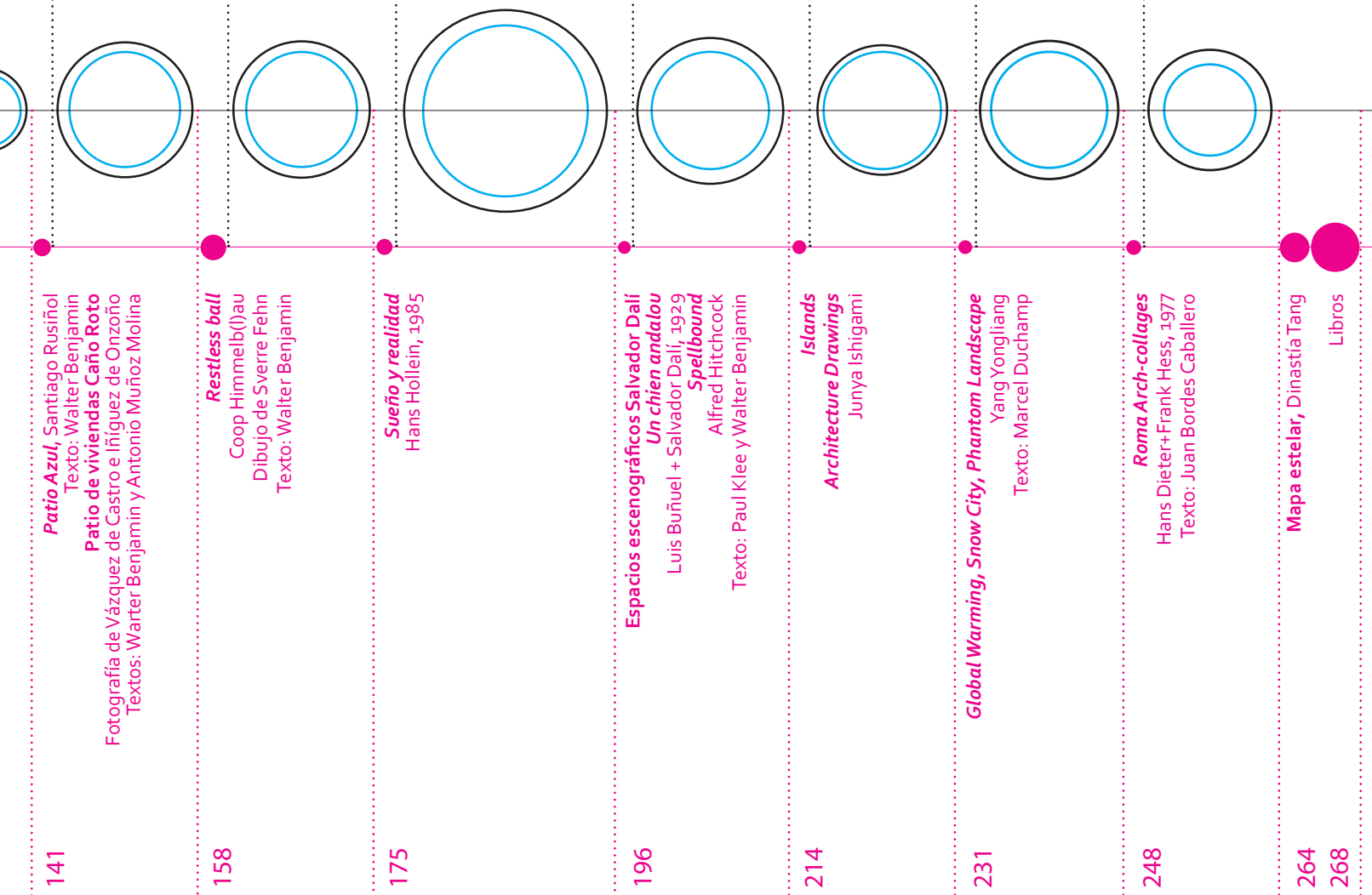


\section{Nuevos paisajes, viejos modelos. Una mirada al Lago de la Mina de As Pontes New Landscapes, Old Models. A Glance at the Lake of As Pontes' Mine}

\section{Esther Valdés Tejera}

Escuela Politécnica Superior, Universidad CEU San Pablo, Madrid

Traducción Translation Esther Valdés y David Amezcúa

\section{Palabras clave Keywords}

Paisaje, mina, As Pontes, Robert Smithson, mirada, naturaleza, artealización, paradigma Landscape, mine, As Pontes, Robert Smithson, glance, nature, artealization, paradigm

\section{Resumen}

A finales de los años sesenta del siglo pasado, el artista Robert Smithson expuso un nuevo modo de mirar los restos abandonados de la industria. Poco después, en Seattle, tomó forma un prototipo de parque público que fue desarrollándose posteriormente. Han pasado más de cuarenta años y los parques postindustriales son ya comunes en nuestras ciudades, si bien es verdad que siguen sorprendiendo a muchos. A partir de la restauración paisajística de la mina de As Pontes (Galicia), nos acercamos al paisaje desde una doble vertiente: por un lado, al paisaje como concepto artístico y por otro, al territorio configurado desde sus principios ecológicos. Desde aquí, invitamos al lector a reflexionar sobre la mirada y el papel de la naturaleza en la construcción del paisaje actual, planteando la posibilidad de hallarnos ante un cambio de modelo.

\section{Abstract}

At the end of the 60's of the 20th century, the artist Robert Smithson presented a new way of looking at the industrial waste. Shortly afterwards, a public park prototype took shape in Seattle, which was subsequently developed. More than forty years later, postindustrial parks have become common in our cities, even though they are still amazing for many people. Taking as an example the environmental restoration carried out in As Pontes' Mine (Galicia), our approach to the landscape is twofold: on the one hand, landscape is approached as an artistic concept, and on the other hand, we have considered the manner in which landscape is built from its very environmental principles. The objective of this article is to invite readers to reflect on our glance and on the role of nature in the construction of today's landscape, while raising the possibility of facing a paradigm shift. 
Non Serviam. No he de ser tu esclavo, madre Natura; seré tu amo. Te servirás de mí; está bien. No quiero y no puedo evitarlo; pero yo también me serviré de ti. Yo tendré mis árboles que no serán como los tuyos, tendré mis montañas, tendré mis ríos y mis mares, tendré mi cielo y mis estrellas.

Y ya no podrás decirme: "Ese árbol está mal, no me gusta ese cielo [...] los míos son mejores".

Yo te responderé que mis cielos y mis árboles son los míos y no los tuyos y que no tienen por qué parecerse: ya no podrás aplastar a nadie con tus pretensiones de vieja chocha y regalona. Ya nos escapamos de tu trampa.

Adiós viejecita encantadora; adiós madre y madrastra, no reniego ni te maldigo por los años de esclavitud a tu servicio. Ellos fueron la más preciosa enseñanza. Lo único que deseo es no olvidar nunca tus lecciones, pero ya tengo edad para andar sólo por esos mundos. Por los tuyos y por los míos.

Una nueva era comienza. Al abrir sus puertas de jaspe, hinco una rodilla en tierra y te saludo muy respetuosamente.

Non Serviam. I shall not be your slave, Mother Nature; I shall be your master. I shall be used by you; it is fine. I do not want and I cannot avoid it; but you shall be used by me. I shall have my trees which will not be like yours, I shall have my mountains, I shall have my rivers and my tides, I shall have my sky and my stars.

And you could not tell me: "This tree is wrong, I don't like that sky [...] mine are better".

I should reply to you that my skies and my trees are mine and not yours and they don't have to look like each other: you would not be able to crush anyone else with your ambitions of old senile and spoiled lady. We escaped from your trap.

Goodbye old enchantress lady; goodbye, mother and stepmother, I shall not reject you nor curse you for the years of slavery at your service. It was the most precious training. My only desire is not to forget your lectures, but now I am old enough to walk alone through this world. Throughout yours and mine.

A new age starts. While its jasper doors opens, I kneel on the land and respectfully greet you.

HUIDOBRO, V. Non Serviam, 1914. (1)
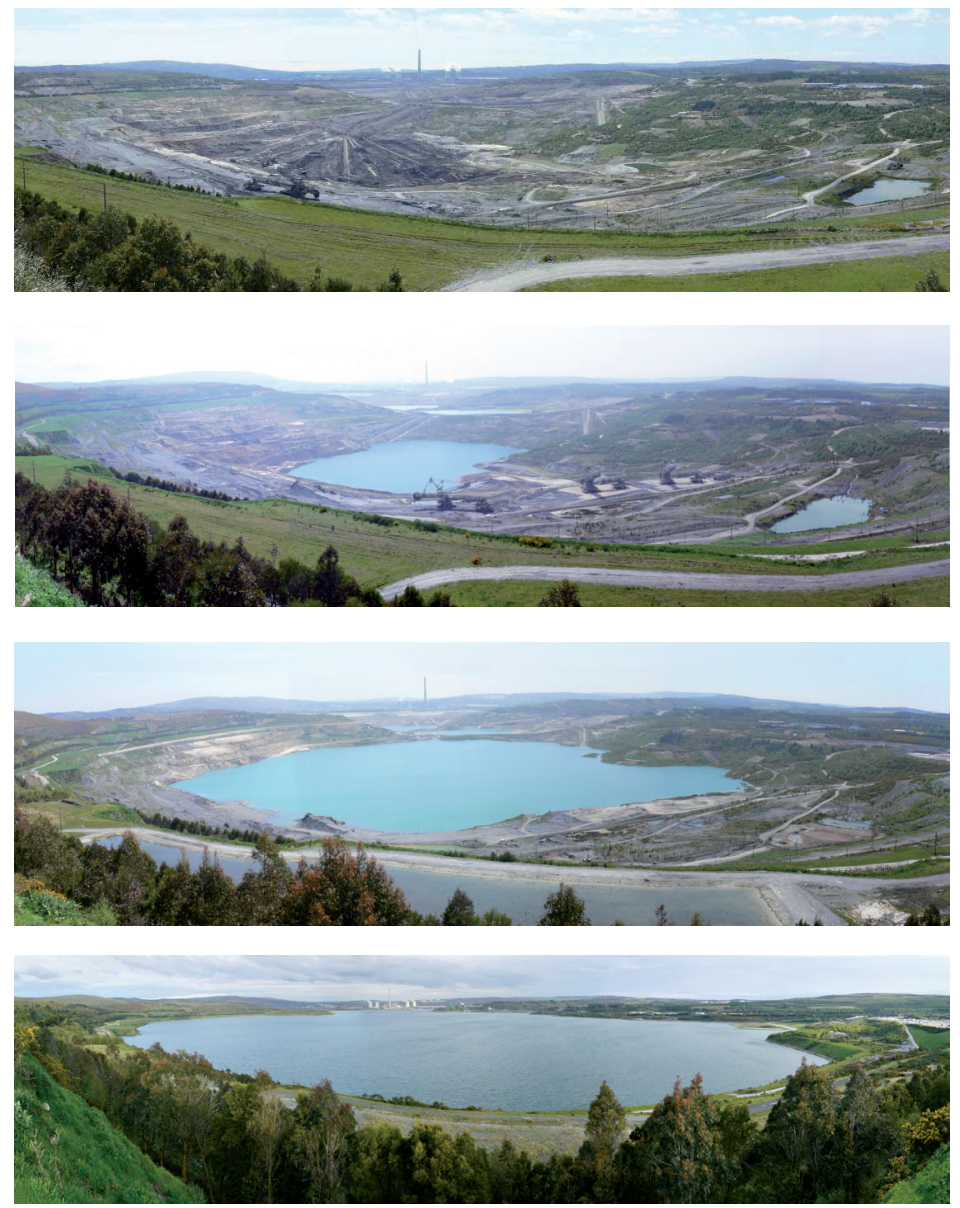

Fig. 1. Mina de As Pontes, noviembre de 2006. (c) Endesa Generación.

Fig. 2. Mina de As Pontes, agosto de 2008.

Volumen del lago: $34,7 \mathrm{Hm}^{3}$, profundidad: $68 \mathrm{~m}$. (c) Endesa Generación.

Fig. 3. Mina de As Pontes, abril de 2009. Volumen del lago: 117,9 $\mathrm{Hm}^{3}$, profundidad: $118 \mathrm{~m}$. (c) Endesa Generación.

Fig. 4. Lago de As Pontes, septiembre 2011.

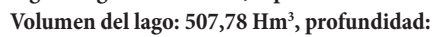
$201 \mathrm{~m}$. () Endesa Generación. 
Recorremos nuestro territorio y observamos los objetos que los pueblan. Autovías trazadas con tiralíneas que atraviesan la orografía del terreno cual caballeros medievales lanza en mano; postes del tendido eléctrico con forma de humanoide descabezado; aerogeneradores para los quijotes del siglo XXI; plantas fotovoltaicas con apariencia de mares chamuscados por un Ra despiadado; hectáreas de monótono monocultivo, polígonos industriales, barrios periféricos o centros comerciales, aparecen dispersos por el territorio a modo de película de terror. 'La invasión de los no lugares'; (2) y de vez en cuando, un espacio en apariencia natural nos permite reposar durante unos segundos la mirada. Un sinfín de paisajes se suceden ante nuestros ojos, esos que actualmente justificamos con el término políticamente correcto de 'paisaje cultural', donde metemos casi todo. Paisajes productivos, tecnológicos, eficientes y democráticos configurados con la finalidad del máximo beneficio por bandera. Hasta aquí todo bien, si no fuera porque cuando los miramos no nos gusta lo que vemos y además, si nos fijamos bien, caemos en la cuenta de que la mirada que nos devuelven es más aterradora aún que la nuestra.

Sabemos que el paisaje tiene las raíces asentadas en la geografía y son la hidrología, la orografía o la edafología las que nos guían en el camino. Sabemos que su piel es ecológica y que los ecosistemas mandan. Sabemos también, que el paisaje lo configura el hombre y que durante siglos, lo ha recorrido y salpicado con infraestructuras, vivienda, industria o agricultura. Y puestos a saber, sabemos que el paisaje es un concepto artístico y que no fueron las ciencias, la tecnología o la economía, sino el arte y la mirada, lo que permitió al hombre, allá por el Quattrocento, descubrir el paisaje por primera vez.

Si unimos estas dos ideas: que el paisaje es un concepto artístico y que estamos rodeados de paisajes de dudosa calidad estética, surge de inmediato la pregunta: ¿no sabemos construir paisajes o lo que no sabemos es mirar? Aunque parezca una dicotomía un tanto reduccionista, no está exenta de cierta lógica. En un primer impulso concluiríamos rápidamente y sin pestañear, que el primer supuesto es el acertado. O como decía Maderuelo: "Si la imagen de este mundo no

We look over our landscapes and observe the objects that colonize them. Highways designed with drawing pen crossing the topography of the land like medieval knights spear in hand; headless humanoid shaped electric poles; wind turbines for the xxI century's quijotes, photovoltaic installations which seem scorched seas by a merciless Ra; acres of monotonous mono-cultivation, industrial areas, shopping malls or suburbs, they are all scattered over the territory as a horror movie. 'The non-sites' invasion'; (2) however, occasionally, an apparently natural space allows us to stand and hold the gaze. Loads of landscapes follow in front of our eyes. Those ones we refer to today as 'cultural landscapes', a term which includes almost everything. Productive, technological, efficient and democratic landscapes are organized under the flag of the maximum benefit. So far so good, except for the fact that we dislike what we see, and if we stared at it, we realize that the returned gaze is even more frightening than ours.

We know that landscape has its roots settled in geography while hydrology, topography or soil science are the ones that guide us along the way. We know that its skin is ecological, and that ecosystems command. We also know that landscape is shaped by the human being who went over it for centuries and sprinkled it with infrastructure, housing, industry or agriculture. And we do know that 




landscape is an artistic concept and that it was not science, technology or economics, but Art and glance which allowed humans, in the Quattrocento to discover the landscape for the first time.

If we link these two ideas: that is, that landscape is an artistic concept, and, on the other hand, that we are surrounded by landscapes of uncertain aesthetic quality, the question immediately arises: Do we ignore how to build landscapes or do we ignore how to look at them? Although it seems to be a reductionist dichotomy, it is quite logical. In a first impulse, we would conclude quickly, without even blinking, that the first assumption is the correct one. Or as Maderuelo said: "If the image of this world is not nice, that is, culturally acceptable, if the landscape we are building is not satisfactory, then it means we are doing things wrong". (3) But if you think about it carefully, it may also be a matter of glances and what happens is that "we live in a world that we have not yet learned to look at". (4) It's been over twenty years since Augé stated so and since then, many things have changed. We have learned how to look at our waste with new eyes, adapting our glance to our time; and with regard to landscape, a new approach have also taken place. But since the improvement is slight, it seems that the key is still missing: could it be that we are using a wrong model? Let's consider a case.

In the 1940's, the construction of a thermal factory started in As Pontes de Garcia Rodriguez, a town council of A Coruña (Galicia). In the 1970's, the factory ended up being the biggest one in Spain. From that moment until its clo- 
es agradable, es decir, culturalmente aceptable, si el paisaje que estamos construyendo no es satisfactorio, entonces es que nos estamos equivocando". (3) Aunque si lo pensamos detenidamente, quizá también sea una cuestión de miradas y lo que aún ocurre es que "vivimos en un mundo que no hemos aprendido a mirar todavía". (4) Han pasado más de veinte años desde esta afirmación de Augé y en ese tiempo han cambiado bastantes cosas. Hemos aprendido a mirar nuestros residuos con ojos renovados adaptando la mirada a nuestro tiempo; y en cuanto al paisaje, también ha habido cambios de enfoque. Pero dado que la mejoría es leve, parece que no acabamos de encontrar la clave, ¿será quizá que nos estamos equivocando de modelo? Veamos un caso.

En los años cuarenta del siglo pasado, en As Pontes de García Rodriguez, un pequeño concejo de A Coruña (Galicia), se inició la construcción de una central térmica que acabaría transformándose, en los setenta, en la más grande de

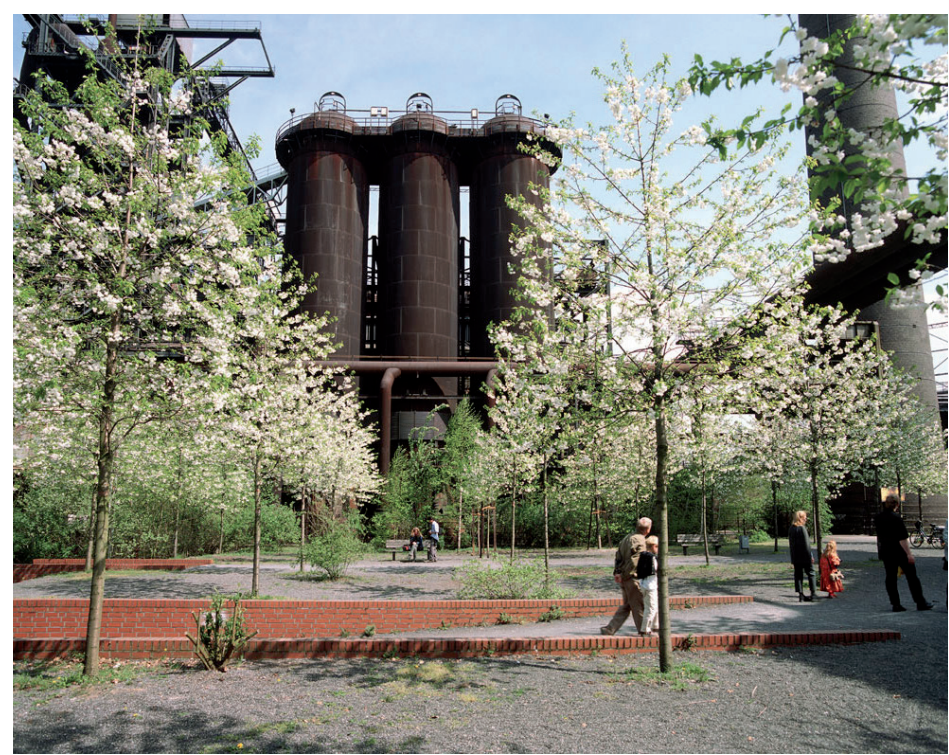

Fig. 6. Duisbourg Nord Park.

Web Latz \& Partner.

the other hand, environmentalists with a big population support, denounced the destruction of ecosystems and landscapes, and demanded the fulfilment of the law. There were some artists, who started working on the land at that time, who were interested in this debate. The well-known earthwork artists such as Robert Morris, Robert Smithson and Michael Heizer, with the art gallery director Virginia Dwan, started touring the country emulating the Beat Generation -On the Road-searching abandoned places of the industry. They looked for sites to inspire them and to place their works.

While Smithson was absorbed on his own debate between site and non-site and the entropy concept, his ideas were taking shape in articles published in specialized magazines and earthworks in the desert. At the same time, he sent loads of letters to the industry companies with sketches and proposals for recovering spaces that had been degraded by industry. He was aware of the industry as a necessity and the inevitability of their waste, and even though he did not share convictions with environmentalists, he was conscious of the deterioration of the environment. In any case, he saw an aesthetic value on the industrial wasteland that only a few of his contemporaries were able to appreciate. This position of engagement with the reality of his time and the need of place for their works, led him to find a solution to the conflict. He believed that artists had a consistent social work in recovering the remains generated by societies, not to turn them into something different to what they were or to recreate a wild nature, but to show the interest inside of them. He wanted to transform these useless and ugly places into art pieces. 

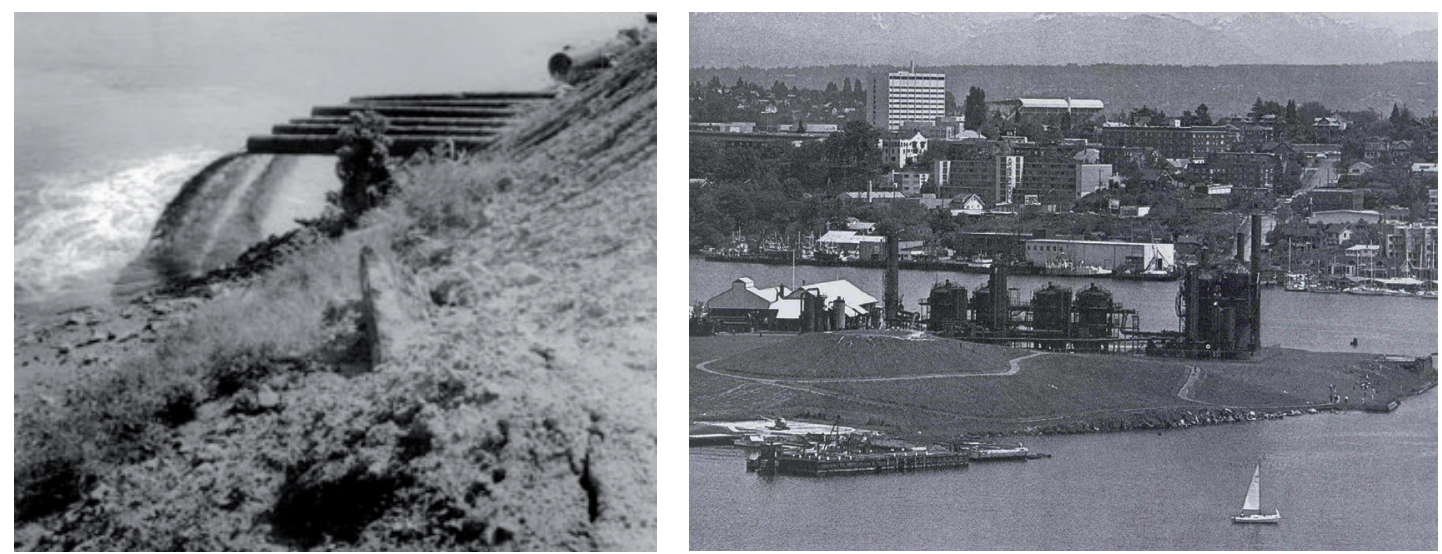

España. Desde entonces y hasta su cierre en 2007 generó la energía eléctrica equivalente al consumo total nacional en un año medio. El material necesario para alimentar la central procedía de una mina de lignito a cielo abierto. El yacimiento consistía en una cuenca sedimentaria de la era terciaria, de unos cuarenta mil años de antigüedad, formada por una 'milhojas' de lignitos y arcillas. En los sesenta años de actividad de la mina se extrajeron 270 millones de toneladas de lignito que dejaron un vacío de 900 millones de metros cúbicos y 230 metros de profundidad, y una montaña de estériles de 160 metros de altura. La superficie total de terreno afectado por la explotación era de 24 kilómetros cuadrados. Un Real Decreto de 1982 obligaba a las empresas explotadoras a realizar trabajos de restauración del espacio natural afectado por las labores mineras. Dos años más tarde y tras el estudio de impacto ambiental realizado por Endesa se comenzó a restaurar la escombrera en un proceso por fases que duraría casi treinta años. Al finalizar la explotación, los trabajos de restauración se centraron en el llenado del hueco de la mina con agua. Con este proyecto, se había creado el mayor lago artificial de Europa. Hoy en día es Endesa Generación la responsable de gestionar y mantener estos terrenos cumpliendo con lo estipulado en la Declaración de Impacto Ambiental aprobada. En un futuro podría pasar la gestión a la Xunta de Galicia.
Fig. 7. Smithson. The Fountain Monument. Web del autor.

Fig. 8. Gas Work Park. Sutherland Lyall.

In this learning process he described a bridge, a platform pump or some pipes discharging waste into a river, as an ironic tour guide would do when he explains The Bridge Monument Showing Wooden Side-walks, The Great Pipes Monument or The Fountain Monument, (5) while he dispelled those images from the concept of romantic ruin. A couple of years before his death occurred in 1973, he had the chance to make a sculpture in an old sand quarry in Holland, called Broken Circle-Spiral Hill. After that, he sent more than fifty proposals of land recovering to mining companies with the support of Timothy Collins -art collector and investor in mining; one of them was Reclamation Project for the Bingham Copper Mining Pit-Utah. There were few answers, but he certainly initiated a new way of looking.

With these actions, Smithson did a multiple proposal; he accepted the geological, historical and ancient past of the place; he transformed obsolete machinery into monuments -Duchamp's ready-made-; he ordered the space with simple geometries; he endowed it with new functions transforming it into an improvised art gallery, and throughout this decontextualized mutation, the work of art made the surrounding visible. As a result of this, the visitor was transformed into an active and attentive spectator. Thus, the viewer was put in the position of looking beyond, perceiving, feeling and experiencing the space created by the work of art, as a pure aesthetic experience. 
Los antecedentes de esta intervención los encontramos desde los sesenta repartidos por la geografía mundial. En aquellos años ya se había aprobado en Estados Unidos una ley similar para la recuperación de minas, lo que provocó un intenso debate entre empresas mineras y ecologistas. Las primeras, obligadas a devolver la naturaleza a su estado original y a eliminar los restos industriales y mineros de la explotación, alegaban altos costes y mayor producción de residuos. Por su parte, los ecologistas, con un importante apoyo de la población, denunciaban la destrucción de ecosistemas y paisajes, y reclamaban el cumplimiento de la ley. Este debate, interesó a algunos artistas de la época que estaban iniciando su andadura en lo que pronto se conocería como Earthworks. Robert Morris, Michael Heizer o Robert Smithson, junto a galeristas como Virginia Dwan, comenzaron a recorrer el país emulando a la Beat Generation -On the Road-, en busca de territorios abandonados por la producción industrial. Buscaban espacios en los que inspirarse y donde emplazar sus obras.

Inmerso Smithson en su propio debate entre site y non-site y el concepto de entropía, sus ideas iban tomando forma de artículos publicados en revistas especializadas y en obras construidas en el desierto. Al mismo tiempo, enviaba cartas con propuestas y bocetos para la recuperación de espacios degradados por la industria a las empresas del sector. Si bien era consciente de la necesidad de la industria y lo inevitable de sus residuos, también lo era del deterioro del medio ambiente aunque no compartiera postura con los ecologistas. En cualquier caso, veía en los yermos industriales un valor estético que pocos contemporáneos suyos eran capaces de apreciar. Esta postura de compromiso con la realidad de su tiempo y la necesidad de espacio para sus obras, le llevaron a pensar una solución al conflicto. Consideraba que los artistas tenían una labor social consistente en recuperar los desechos que generaba la sociedad, no para convertirlos en algo distinto a lo que eran o para recrear una naturaleza salvaje, sino para mostrar el interés que había en ellos. Quería convertir estos espacios inútiles y feos para la mayoría, en obras de arte.

En este aprendizaje describió un puente, una plataforma de bombeo o las tuberías que vertían residuos a un río, como lo haría un irónico guía turístico

Richard Haag proposed the regeneration project of the Gas Work Park in Seattle, in similar terms. In 1970 he was commissioned to project the regeneration of a gas plant in Union Lake, and his proposal was to intervene as little as possible, to keep some industrial elements and to decontaminate soil by phytoremediation. The first reaction to his project was a complete rejection, to the point of invalidating the authorization to designate the new park with the name of a lady in town. But after many researches, management and hard work of awareness assumed by the landscape architect, in 1973 Haag obtained the support of the council and the works started, lasting several years. The minimum intervention criterion implied the assumption of controversial decisions such as keeping the distillation towers as sculptures, avoiding to plant trees, or maintaining the lawns without irrigation. The treatment of the contaminated soil was one of the most important processes for Haag. His approach was summed up by William Thompson as follows: "To search for and preserve the spirit of the place, to do as much as possible with the least available and to simplify its own resources". (6) A public park prototype was thus created.

From that moment on, and mainly since the 90's, many examples of post-industrial parks were performed out. Projects like Duisburg Nord (Ruhr Valley, Germany), Parque das Pedreiras (Curitiba, Brazil) or Eden Project (Cornwall, England) are well known as good examples of how 'the green' blurs the images and humanizes the industrial wastelands. Like Smithson's pieces of art, these interventions succeeded in transforming the space and the viewer with it, but unlike them, the standardization 
mostrando el Monumento de las Direcciones Dislocadas, la Fuente infernal o la Fuente Monumental, (5) al tiempo que alejaba esas imágenes del concepto de ruina romántica. Un par de años antes de su muerte acaecida en 1973, tuvo la oportunidad de realizar una escultura en una antigua cantera de arena en Holanda, construyendo la obra Broken Circle-Spiral Hill. A partir de entonces y con la ayuda de Timothy Collins -coleccionista de arte e inversor en minería- envió más de cincuenta propuestas de recuperación de terrenos a otras tantas empresas mineras como Reclamation Project para la Bingham Copper Mining-Pit en Utah. Pocas fueron las respuestas, pero sin duda se había iniciado una nueva forma de mirar.

Con estas acciones, Smithson hacía una propuesta múltiple; aceptaba el pasado remoto, geológico e histórico del lugar; transformaba la maquinaria obsoleta en monumento -ready-made duchampiano-; ordenaba el espacio con geometrías simples; lo dotaba de nuevos usos convirtiéndolo en galería de arte improvisada, y en toda esta mutación descontextualizada, la obra cobraba fuerza y hacía visible el entorno, transformando a su vez al visitante en atento y activo espectador. Así, ponía al observador en disposición de mirar más allá, de percibir, sentir y vivir el espacio generado por la obra de arte, como pura experiencia estética.
Fig. 9. Repton, imagen del paisaje existente, Wentworth, South Yorkshire. Barlow Rogers. Fig. 10. Repton, propuesta de proyecto, Wentworth, Yorkshire. Barlow Rogers.
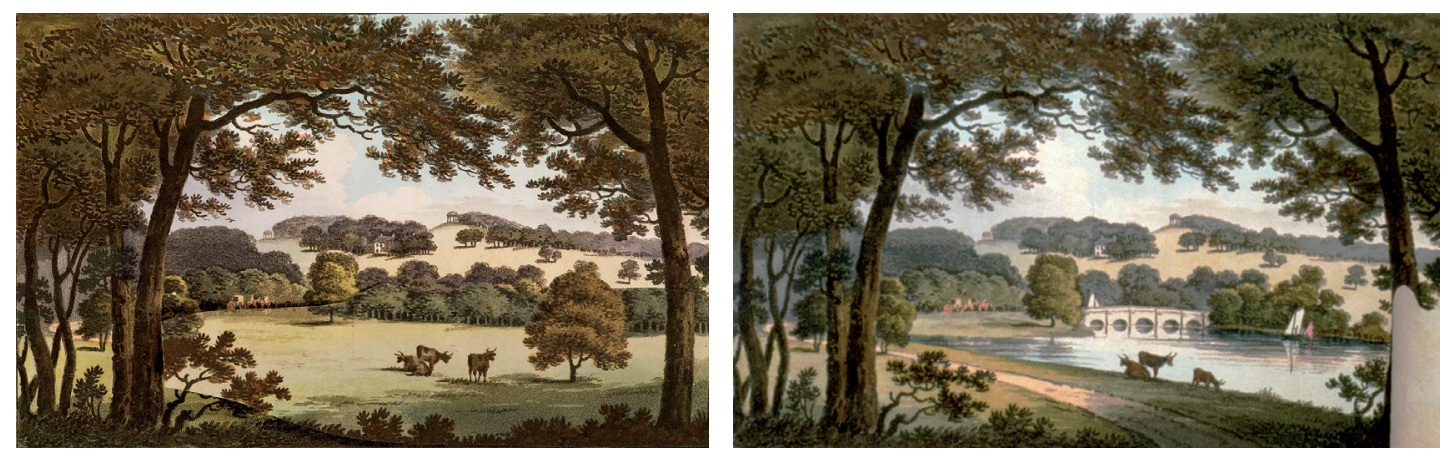

and the recycle of the industrial wastes were carried out with water and vegetation. Even though these forms are being integrated into our concept of landscape, their presence in parks still leaves much of the population bewildered.

Returning to the landscape restoration of the As Pontes mine, in 2007 there was a completely anthropic scenario. Like any other mines, this landscape had a strange and powerful interest arising from its own geology as well as the memory of the place. However, a choice should be taken, and to fill the mine with water was controversial. While the authorities supported the project, environmental groups and some experts pointed out some possible problems, such as the difficulty of getting sufficiently high quality water to generate and sustain life in the lake. Nowadays, and with the results in our hands, it could be stated that, while from the point of view of the gaze, the new lake have had a deep positive visual impact, regarding the building of the landscape, the fundamental achievement has been the environmental restoration of the exterior dump.

Since the beginning of the mining development and until its end in 2002, the storage of waste material outside the mine hole was necessary. The dump was composed of clay-silt sterile of the mineral deposit, phyllites that make up the edge of it, and ashes produced by the power station. In its final configuration the dump covered an area of 1.150 hectares, with 720 million cubic meters volume and 160 meters height. Erosion control, storm water runoff channel, dump's morphology and slopes design, selective management of sterile or the discharge of materials were deeply researched, and the decisions taken were decisive for 
Este mismo proceso es el que llevó al paisajista Richard Haag, probablemente influido por las publicaciones del artista, a plantear la recuperación del Gas Works Park de Seattle en términos similares. Cuando en 1970 le encargaron el plan de regeneración de una fábrica de gas en el lago Unión, su propuesta fue la de intervenir lo menos posible, mantener algunos elementos industriales y descontaminar los suelos por fitorremediación. La primera reacción al proyecto fue de rechazo absoluto, hasta el punto de ser retirada la autorización para designar el nuevo parque con el nombre de una dama de la ciudad. Pero después de muchos estudios, gestiones y una intensa labor de concienciación por parte del paisajista, en 1973 Haag consiguió el apoyo del Ayuntamiento y dieron comienzo unas obras que durarían varios años. El criterio de la mínima intervención supuso adoptar decisiones polémicas como mantener algunas torres de destilación a modo de esculturas, no plantar arbolado o que las praderas de césped no tuvieran riego. Uno de los procesos en el que Haag puso enorme empeño fue en el tratamiento de los suelos altamente contaminados. El enfoque de Haag era resumido por William Thompson con las siguientes palabras: "Buscar y conservar el espíritu del lugar, hacer lo máximo posible con lo mínimo disponible y simplificar expresamente los medios propios". (6) Se creó así un prototipo de parque público.

Desde aquella fecha y fundamentalmente a partir de los noventa, han sido muchos los ejemplos de parque post-industrial que se han llevado a cabo. Bien conocidos son el proyecto de Duisbourg Nord (valle del Rhur, Alemania), el Parque das Pedreiras (Curitiba, Brasil) o Eden Project (Cornualles, Inglaterra), ejemplos perfectos de cómo 'lo verde' desdibuja y humaniza los yermos industriales. Al igual que las obras de Smithson, consiguen transformar el espacio y con él al espectador, aunque a diferencia de ellas, la normalización y el reciclaje de los restos de la industria se lleva a cabo con ayuda del agua y la vegetación. Y si bien estas formas se han integrado en nuestro concepto de paisaje, su presencia sigue dejando perpleja a buena parte de la población.

Volviendo a la restauración paisajística de la mina de As Pontes, el escenario que allí se presentaba en 2007 era un espacio antropizado hasta lo indecible.

establishing the proper surface capable to generate plant covers for stable ecosystems. Twenty years of research and landscape restoration have resulted in several interrelated ecosystems that are integrated into the natural setting and offer new possibilities of use. In the surrounding area of the former mine, Eume's tributaries flow again; in the dump there are corpses of alder and birch trees, of gorses and brooms where roe deer, wild boar, hares and moles live; in the meadows, the ponds and the wetlands, there are frogs, otters and grey herons as well as storks in its migratory path; earthworms aerate the soil and oxygenate it while returning the organic material; in the lake, the various species of invertebrates, fish and algae are beginning to colonize the water. 180 vertebrate species were inventoried in 2011.

The lake removed the anthropic landscape of the mine hiding it under its water. The new landscape is closer to the idea of a 'return to Arcadia' than to Smithson's glance. If we compare two photographs of As Pontes -the mine in 2006 and the lake in 2011- images of Humphrey Repton's Red Books come inevitably to our mind. Those beautiful books full of drawings with which, in the eighteenth century, the landscape architect convinced his clients how appropriate the project was. Planting a forest in front of a factory to cover an unpleasant view, building an abbey to create a picturesque effect in the distance or changing the course of a river building an artificial lake near to a meadow were frequent proposals to transform the properties of an aristocrat in a landscape painting. As Alain Roger stated, Poussin, Claude Lorrain or Ruysdale 'artealizated' (7) the landscape in situ in the seventeenth century, that is, taught us to look at the land with new eyes through his paintings; in the 
Al igual que otras minas, tenía un extraño y poderoso interés que surgía de la propia geología y de la memoria del lugar, sin embargo había que tomar una decisión y la de llenar la mina de agua no estuvo exenta de polémica. Si bien contaba con la aprobación de la Xunta de Galicia, grupos ecologistas y algunos expertos apuntaban las dificultades que un proyecto así podría acarrear tales como la dificultad para conseguir una calidad de agua suficiente para generar y mantener vida en el lago. Actualmente y vistos los resultados, si desde el punto de vista de la mirada la aparición del lago ha tenido un impacto positivo de importantes consecuencias, el valor fundamental en cuanto a la construcción del paisaje se refiere, ha sido la restauración medioambiental de la escombrera exterior.

Desde los comienzos de la explotación hasta el año 2002 fue necesario depositar el material estéril extraído en una zona externa a la cuenca productiva. La escombrera estaba compuesta por los estériles limo-arcillosos del yacimiento, las filitas que conforman el borde del mismo y las cenizas producidas por la Central Térmica. En su configuración final ocupaba una superficie de 1.150 hectáreas, un volumen de 720 millones de metros cúbicos y una altura de 160 metros. Los estudios realizados y las decisiones tomadas en cuanto al control de la erosión, la canalización de aguas de escorrentía, la morfología de la escombrera y el diseño de los taludes, la gestión selectiva de estériles o el vertido de los materiales, fueron decisivas a la hora de establecer superficies capaces de generar cubiertas vegetales autosuficientes en las que albergar ecosistemas estables. Veinte años de investigación y restauración paisajística han dado como resultado distintos ecosistemas interrelacionados entre sí e integrados en el entorno natural que ofrecen nuevas posibilidades de uso. En los alrededores de lo que fue la mina corren de nuevo los afluentes del Eume; en la escombrera hay bosquetes de alisos y abedules, de tojos y retamas donde habitan corzos, jabalíes, liebres y topos; en las praderas, charcas y humedales, viven ranas, nutrias, garzas reales o cigüeñas en paso migratorio; las lombrices y larvas airean la tierra oxigenando el suelo y devolviendo la materia vegetal; en el lago, las distintas especies de invertebrados, peces y algas empiezan ya a colonizar las aguas. 180 especies de vertebrados fueron inventariadas en 2011.

same way, Smithson 'artealizated' in situ industrial landscapes of the twentieth century. And if William Kent, Lancelot Brown or Repton, 'artealizated' the land in situ transforming it into landscape and taking the idealized painters' glance of nature as a model, As Pontes seems to appear as a case of 'artealization' in situ. With this intervention, we come back to the old models of the past but taking one more step. On the one hand, the picturesque model of the English landscape is used in the image provided by the lake, the hill and the vegetation; on the other hand, the natural model is used from its roots as a tool for the ecological restoration.

There was a need of a great engineering and landscape work in which research and studies were conducted in different fields; technology and economics, geography and ecology, aesthetics and function joined together to make life succeed. More than year has passed since the inauguration of As Pontes Lake. It will take time for the ecosystems to be stabilized and the food chain to get balanced, and perhaps we will never be quite sure that this enormous footprint in the land can be erased without consequences. Some machinery that for years scratched the bowels of the earth remains in the lakefront bearing witness of the past as Smithsonian monuments. Scratches that allowed us to see the folds and thrust faults which remind us that geology shapes our landscapes and sustains them; that ecosystems and societies grow up upon it, building a rich and complex landscape easy to understand, appreciate and care. It do not need any explanation, intricate learning or diatribes about sustainability, because it has the simplicity of what man knows from the beginning of time, the simplicity that never fails. 

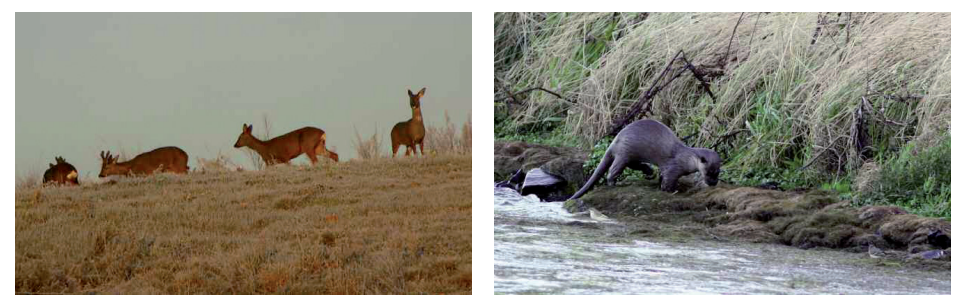

Si el lago ha hecho desaparecer la imagen antropizada de la mina escondiéndolo bajo sus aguas, el nuevo paisaje creado está más cerca de la idea de una 'vuelta a la Arcadia', que de la mirada de Smithson. Si vemos al tiempo dos fotografías de As Pontes -la de la mina en 2006 y la del lago en 2012-inevitablemente nos vienen a la memoria las imágenes de los Red Books de Humphrey Repton. Aquellos preciosos libros repletos de dibujos con los que el paisajista inglés convencía al cliente en el siglo XviII de lo adecuado de su proyecto. Plantar un bosque delante de una fábrica para tapar una vista desagradable, construir una abadía creando un efecto pintoresco en la lejanía o desviar el curso de un río generando un lago artificial junto a una pradera, eran propuestas frecuentes para conseguir convertir la finca de un aristócrata en una pintura de paisajes. Como afirmó Alain Roger, Poussin, Claudio de Lorena o Ruysdale 'artealizaron' (7) el paisaje in visu en el siglo Xvir, es decir, nos enseñaron a mirarlo con nuevos ojos a través de sus pinturas; del mismo modo Smithson 'artealizó' in visu los paisajes de la industria del siglo Xx. Y si William Kent, Lancelot Brown o Repton 'artealizaron' el país in situ transformándolo en paisaje a partir del modelo de naturaleza idealizada por los pintores, As Pontes aparece ahora como un caso de 'artealización' in situ. Con esta intervención, parecemos retroceder en el pasado volviendo al viejo modelo, aunque dando un paso más. Por un lado, retoma el modelo pintoresco del paisajismo inglés en la imagen generada por el lago, la colina y la vegetación; por otro, utiliza el modelo natural desde sus raíces como herramienta para la restauración ecológica.

Fue necesaria una importante obra de ingeniería y paisajismo en la que se realizaron investigaciones y estudios en diferentes campos; se unieron tec-
Figs. 11, 12 y 13. Corzos, nutrias y buitrón sobre un tallo de gramínea en el lago y la escombrera de As Pontes. $\odot$ Endesa Generación.

Muñoz Molina wrote recently that "[...] literature or music, art, are the antidotes of this stunning throwaway world, of a somewhat neurotic and distracted avidity for the unseen, the unusual world that at the very beginning of its shining is already fading into oblivion. What is actually valuable never ends or becomes obsolete. It has the ecological persistence of the things that last, while they are worn out, and the more you use them, the better they become; not because they are refractory to time, and therefore inert or immobile, but because they sail in the flow of time, so that they are ancient and contemporary at the same time, the exact reverse of consumption". (8)

The mine reclamation laws faced us with the industrial waste reality and forced us to find solutions. Smithson's aesthetic proposals taught us to look at them with new eyes. If Richard Haag was a pioneer in transforming industrial waste into public parks with aesthetical and ecological criteria, Peter Latz spread the message, normalized its aesthetic and deepened into scientific aspects. Nowadays As Pontes, with its great scale and its social, environmental and economic impact arises as a distinct landscape intervention. Ecology opens the door to the future survival of landscapes and societies, and aesthetics encourage us to appreciate and to take care of them. In sum, a collaboration from different fields and a model change. The industrial revolution passed through, the technological one surrounds us and the ecological one is already in our way; maybe, we have to learn again how to look at nature. If at the beginning of the twentieth century, the poet Vicente Huidobro verbalized a general feeling, embraced the machine and said goodbye to 
nología y economía, geografía y ecología, estética y función para conseguir que finalmente la vida se impusiera. Ha pasado más de un año desde la inauguración del lago de As Pontes. Tendrá que pasar tiempo aún hasta que los ecosistemas estén estabilizados y la red trófica se mantenga en equilibrio y quizá nunca estemos del todo seguros de que una huella tan ingente en el territorio se pueda borrar sin consecuencias. A orillas del lago, como testigo del pasado, han quedado cual monumentos smithsonianos, parte de la maquinaria que durante años arañó las entrañas de la tierra. Arañazos que permitieron ver los plegamientos y cabalgamientos que nos recuerdan que la geología da forma a nuestros paisajes y los sustenta; que sobre ella se asientan ecosistemas y sociedades creando un paisaje rico y complejo fácil de entender, de apreciar y de cuidar; que no necesita explicaciones y aprendizajes complejos, ni diatribas en torno a la sostenibilidad, porque contiene la sencillez de lo que el hombre conoce desde el principio de los tiempos, la sencillez de lo que nunca falla.

Escribía hace poco Muñoz Molina que “[...] la literatura o la música, el arte, son antídotos de este mundo aturdido del usar y tirar, de la avidez entre distraída y neurótica por lo nunca visto, lo inusitado que en el momento mismo de brillar ya está desvaneciéndose en el olvido. Lo valioso de verdad no se agota, ni se queda obsoleto. Tiene la persistencia ecológica de las cosas que duran gastándose y que se vuelven mejores cuanto más se usan; no porque sean refractarias al tiempo, y por lo tanto inertes o inmóviles, sino porque navegan en el flujo del tiempo, de modo que son a la vez antiguas y contemporáneas, el reverso exacto del consumo. (8)

Las leyes de recuperación de minas nos enfrentaron a la realidad de los restos industriales y nos obligaron a buscarles solución. Propuestas estéticas como las de Smithson nos enseñaron a mirarlos con ojos renovados. Si Richard Haag fue pionero en su reconversión como parques públicos desde el punto de vista estético y ecológico, Peter Latz difundió el mensaje, normalizó su estética y profundizó en los aspectos científicos. Ahora, As Pontes, -dada su escala y su repercusión social, medioambiental y económica- aparece como un ejemplo distinto de intervención paisajística. Es la

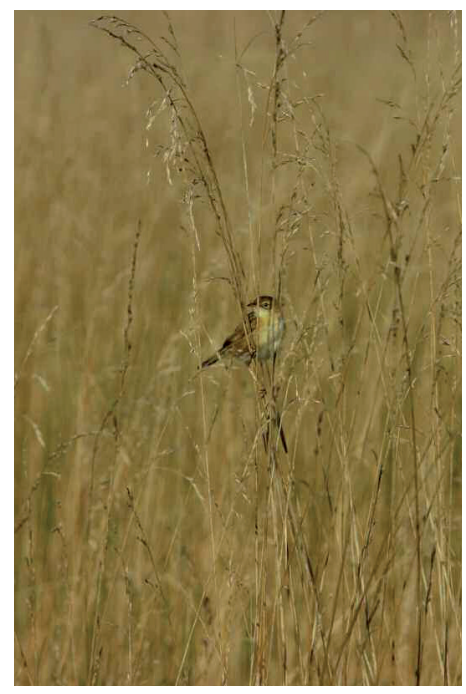

Figs. 11, 12 y 13. Corzos, nutrias y buitrón sobre un tallo de gramínea en el lago y la escombrera de As Pontes. (C) Endesa Generación. an old nature which he called "old senile and spoiled lady", perhaps, a century later, it is time to shift paradigm. Slowing down the global warming is one of our biggest challenges for the XXI century and understanding sustainability in a global sense, as the only way to ensure the survival of future generations, is already an inescapable requirement. Building landscapes from our glance has implications that go beyond the pure pleasure for our senses. Conceiving landscapes in a functional and efficient way is almost always necessary, but doing it by the hand of environmental awareness is already ineluctable. We are Nature and the Earth, for the moment, the only possible place to inhabit. 
ecología la que nos abre la puerta a la pervivencia futura de los paisajes y las sociedades, y es la estética la que nos hace apreciarlos y querer cuidarlos. En suma, colaboración desde todos los campos y cambio de modelo. La revolución industrial pasó, la tecnológica nos inunda y la ecológica está ya en marcha; quizá tengamos que aprender de nuevo a mirar la naturaleza. Si a principios del siglo xx el poeta Vicente Huidobro verbalizó el sentir general, abrazó la máquina y se despidió de la naturaleza llamándola "vieja chocha y regalona” quizá, un siglo después, ha llegado el momento de cambiar de paradigma. Frenar el cambio climático es uno de nuestros mayores retos para el siglo xxi y entender la sostenibilidad en sentido global como el único medio para asegurar la pervivencia de las generaciones futuras es ya una exigencia ineludible. Construir paisajes desde la mirada tiene repercusiones que van más allá del puro placer para los sentidos, concebirlos de modo funcional y eficiente es casi siempre necesario, pero hacerlo de la mano de la conciencia medioambiental es ya ineluctable. Somos Naturaleza y la Tierra, por el momento, el único lugar posible en el que habitar.

\section{REFERENCIAS}

AUGÉ, M. Los no lugares. Espacios del anonimato. Una antropología de la sobremodernidad. Barcelona: Gedisa editorial, 2000. BARLOW ROGERS, E. Landscape Design. A Cultural and Architectural History. Nueva York: Abrams, 2001.

MADERUELO, J. (ed.). Paisaje y Pensamiento. Madrid: Abada Editores, 2006.

MUÑOZ MOLINA, A. 'Admirando a Galdós', en la revista Babelia 1.136. EL PAÍS, 31 de agosto de 2013.

SMITHSON, Robert. Un recorrido por los monumentos de Passaic, Nueva Jersey. Barcelona: GG Mínima, 2006.

ROGER, Alain. Breve tratado del paisaje. Madrid: Biblioteca Nueva, 2007. Colección Paisaje y Teoría.

SMITHSON, Robert. Entrevista con Alison Sky, 'Entropy Made visible', en HOLT, Nancy (ed.). The Writings of Robert Smithson.

Nueva York: New York University Press, 1979.

SUTHERLAND LYALL. Landscape: Diseño del espacio público. Barcelona: Gustavo Gili, 1991.

WEILACHER, Udo. Between Landscape Architecture and Land Art. Basel: Birkhäuser, 1999.

VV.AA. Los habitantes de la escombrera. Universidad de Santiago de Compostela, Endesa Generación, As Pontes de García Rodriguez, 2007. VV.AA. Riqueza Restaurada. Historia de la mina de As Pontes. Endesa Generación, 2011.

\section{REFERENCES}

AUGÉ, M. Non-Places: An Introduction to Supermodernity. Translated by John Howe. London: Verso Publisher, 1995.

BARLOW ROGERS, E. Landscape Design. A Cultural and Architectural History. New York: Ed. Abrams, 2001.

MADERUELO, J. (ed.). Paisaje y Pensamiento. Madrid: Abada Editores, 2006.

MUÑOZ MOLINA, A. 'Admirando a Galdós', in Babelia magazine 1.136. EL PAÍS, 31st August 2013.

SMITHSON, Robert. 'A Tour of the Monuments od Passaic, New Jersey'. First published in Artforum Magazine. New York, December 1967. ROGER, Alain. Court traité du paisage. Paris: Éditiones Gallimard, 1997.

SMITHSON, Robert. Interview with Alison Sky, 'Entropy Made visible', in HOLT, Nancy (ed.). The Writings of Robert Smithson. New York: New York University Press, 1979.

SUTHERLAND LYALL. Landscape: Diseño del espacio público. Barcelona: Gustavo Gili, 1991.

WEILACHER, Udo. Between Landscape Architecture and Land Art. Basel: Birkhäuser, 1999.

VV.AA. Los habitantes de la escombrera. Universidad de Santiago de Compostela, Endesa Generación, As Pontes de García Rodriguez, 2007.

VV.AA. Riqueza Restaurada. Historia de la mina de As Pontes. Endesa Generación, 2011. 


\section{NOTAS}

1. HUIDOBRO, V. 'Non Serviam' en Manifiestos. Santiago de Chile: Mago, 2009.

2. Uso literario del término a mitad de camino entre los nolugares transitorios y carentes de identidad de Augé y los nonsite vacíos y desubicados de Smithson.

3. MADERUELO, J. (ed.). Paisaje y Pensamiento. Madrid: Abada Editores, 2006. $251 \mathrm{p}$.

4. AUGÉ, M. Los no lugares. Espacios del anonimato. Una antropología de la sobremodernidad. Barcelona: Gedisa editorial, 2000.42 p.

5. SMITHSON, Robert. Un recorrido por los monumentos de Passaic, Nueva Jersey. Barcelona: GG Mínima, 2006.

6. SUTHERLAND LYALL. Landscape: Diseño del espacio público. Barcelona: Gustavo Gili, 1991. 207 p.

7. ROGER, Alain. Breve tratado del paisaje, Colección Paisaje y Teoría. Madrid: Biblioteca Nueva, 2007.

8. MUÑOZ MOLINA, A. 'Admirando a Galdós', en Babelia,

1.136. EL PAÍS, 31 de agosto de 2013. 3 p.

\section{NOTES}

1. HUIDOBRO, V. 'Non Serviam' in Manifiestos. Santiago de Chile: Mago, 2009. Own translation.

2. Literary use of the term half-way between the transitory and unidentified non site of Marc Augé and the void and out of place non-site of Robert Smithson.

3. MADERUELO, J. (ed.). Paisaje y Pensamiento. Madrid: Abada Editores, 2006. 251 p. Own translation.

4. AUGÉ, M. Non-Places: An Introduction to Supermodernity.

Trans. by John Howe. London: Verso Publisher, 1995. pp. 35-36. 5. SMITHSON, Robert. 'A Tour of the Monuments od Passaic, New Jersey'. First published in Artforum Magazine. New York, December 1967.

6. SUTHERLAND LYALL. Landscape: Diseño del espacio público. Barcelona: Gustavo Gili, 1991. 207 p. Own translation.

7. ROGER, Alain. Court traité du paisage, Paris: Éditiones Gallimard, 1997.

8. MUÑOZ MOLINA, A. 'Admirando a Galdós', in Babelia 1.136. EL PAÍS, 31st August 2013. 3 p. Own translation.

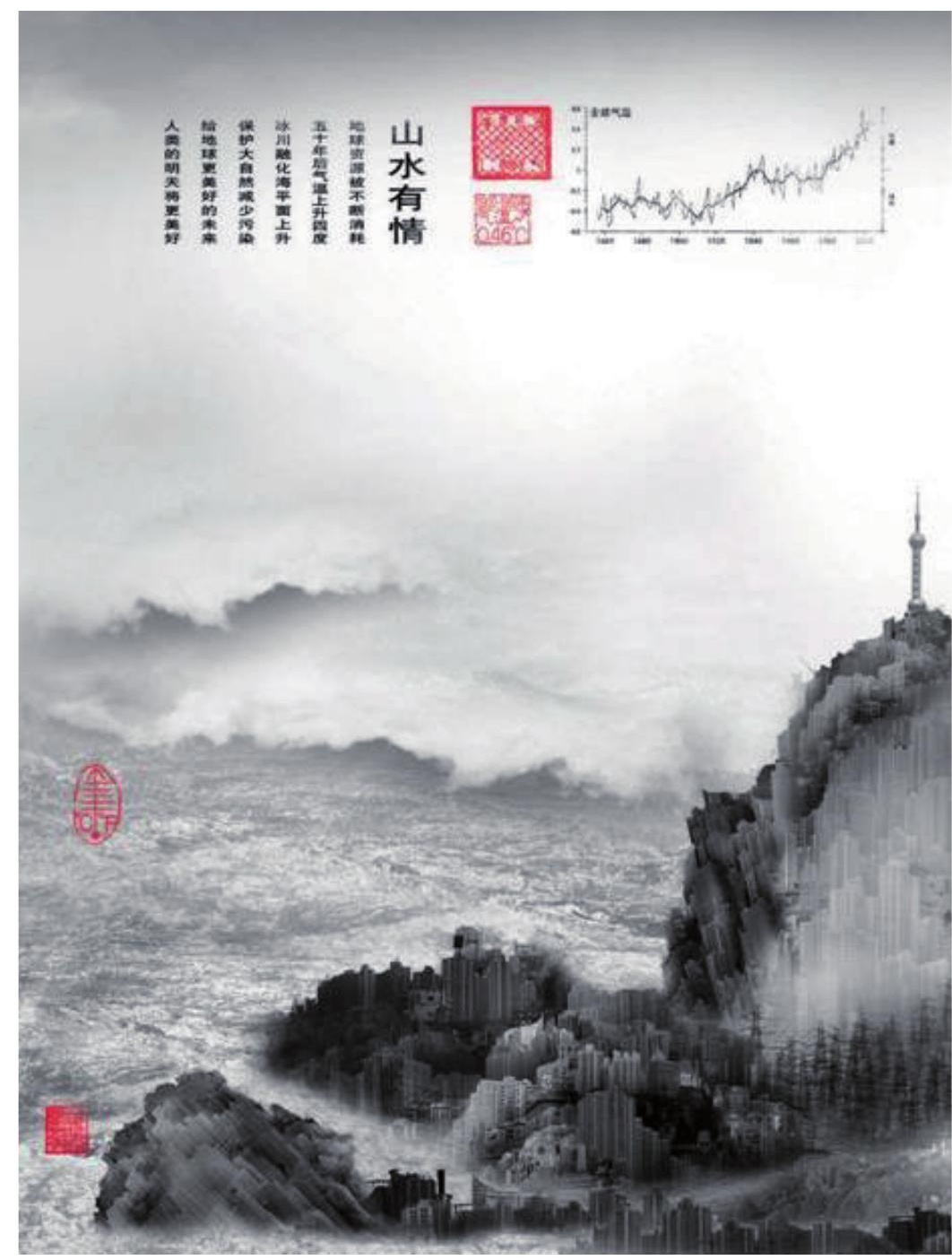

